\title{
浙江省珍稀濒危植物物种多样性保护的关键区域
}

\author{
胡绍庆 ${ }^{1}$ 丁炳扬 $^{2}$ 陈征海 ${ }^{3}$ \\ 1 (杭州植物园, 杭州 310013) \\ 2 (浙江大学生命科学学院, 杭州 310012) \\ 3 (浙江省森林资源监测中心，杭州 310020))
}

摘要: 浙江省植物资源丰富, 有野生维管植物 215 科 1196 属 3283 种, 其中包含了我国特有属 49 个, 浙江省特有植 物约 200 余种, 许多物种十分稀少, 并受到严重威胁, 亟待保护。但浙江省需优先保护的植物物种的分布并不是均 匀的,有些地区的重要保护对象比较集中, 对这些地区我们应该给予更多的保护。本文根据维管植物物种多样性、 珍稀濒危植物的物种数量及个体数量特征、受威胁状况以及浙江省特有植物的分布情况, 提出了浙江省珍稀濒危 植物保护的 7 个关键区域: 以西天目山为中心的浙西北山区，以古田山为中心的浙西山区，以九龙山为中心的浙西 南山区, 以凤阳山 - 百山祖为中心的浙南山区, 以括苍山为中心的浙东山区, 以天台山为中心的浙东丘陵, 以普陀 山为中心的舟山群岛。最后提出了浙江省植物物种多样性保护的几点建议。

关键词：珍稀濒危植物，物种多样性，就地保护，关键区域，浙江省

中图分类号:Q16 文献标识码 : A 文章编号 : 1005-0094(2002)01-0015-09

\section{The critical regions for conservation of rare and endangered plant species diversity in Zhejiang Province}

HU Shao-Qing ${ }^{1}$, DING Bing-Yang ${ }^{2}$, CHEN Zheng-Hai ${ }^{3}$

1 Hangzhou Botanical Garden, Hangzhou 310013

2 College of Life Sciences, Zhejiang University, Hangzhou 310012

3 Zhejiang Forest Resource Monitoring Center, Hangzhou 310020

Abstract : Zhejiang Province is rich in plant resources. There live a total of 215 families , 1196 genera and 3283 species of wild vascular plants , including 49 genera endemic to China and 200 species endemic to Zhejiang. Many species have become rare and threatened, and therefore, should be conserved as soon as possible. However, these rare and endangered plant species are not distributed evenly. Attention should be given to the regions where more plant species deserving protection exist. According to plant diversity, species richness of rare and endangered plants, and their individual quantitative features , imperiled status, and the distribution of endemic plant in Zhejiang Province, seven critical reserve regions for plant species diversity protection are suggested. They are northwest mountains (centered around Xitianmu Mountain), west mountains (centered around Gutian Mountain), southwest mountains ( centered around Jiulong Mountain), south mountains ( centered around Fengyang and Baishanzu Mountains), east mountains ( centered around Kuocang Mountain), east hills (centered around Tiantai hill land) , and Zhoushan Archipelago ( centered around Putuoshan Island). Measures to protect plant diversity in Zhejiang are suggested.

Key words : rare and endangered plants, species diversity , in situ conservation, critical regions , Zhejiang Province 
江省维管植物区系和资源调查工作暂告一段落, 为 生物多样性的保护和持续利用提供了最基础的资 料。但对于生物多样性保护来说, 这只是一个良好 开端，大量的工作有待我们去完成。1997 年以来， 作者参加了《浙江省国家重点保护野生植物资源调 查与监测技术研究》项目，对 34 种国家重点监测物 种和 43 种省级珍稀濒危植物 (以下简称目的物 种”) 进行了调查，这是我省首次对重点保护的野生 植物的资源数量、分布面积、生境及保护现状等方面 进行多物种数量化系统调查。本文在对上述资料分 析研究的基础上, 提出 7 个浙江省珍稀濒危植物物 种多样性保护的关键区域及其划分依据, 并提出加 强保护的对策。

\section{1 浙江珍稀濒危植物的物种多样性}

\section{1 维管植物物种多样性概况}

浙江省地处亚热带季风气候区,自然条件优越， 同时由于地质历史古老，生境复杂，好育了丰富的古 老植物和众多的特有物种。现已知有野生维管植物 215 科 1196 属 3283 种 (不包括种下分类群) , 其中
蕨类植物 49 科 116 属 499 种, 裸子植物 7 科 21 属 26 种, 被子植物 159 科 1059 属 2758 种。浙江的维 管植物的种类和数量位居全国第 $9 \sim 10$ 位, 在我国 东南植物区系中占有重要地位 (浙江植物志编委 会 ,1993)。

\section{2 特有性分析}

浙江省野生种子植物中包含了我国特有属 49 个(郑朝宗等,1998)、浙江特有植物 200 余种。这 些特有属、种的分布呈斑块状聚集在某些区域( 见 表 1)。这些区域是浙江省中国特有属和浙江特有 植物的集中分布所在, 保护这些地区的植物多样性 对我国的生物多样保护具有重要意义。

根据对本次国家重点保护野生植物调查的 77 个目的物种的分析, 发现它们在植物区系中的特有 现象十分明显, 其中中国特有属有 12 个(应俊生, 1994 ), 如银杏属( Ginkgo)、金钱松属 (Pseudolarix)、 白豆杉属 (Pseudotaxus)、伯乐树属 (Bretschneidera)、 腊梅属( Chimonanthus)、七子花属 (Heptacodium)、杜 仲属 (Eucommia)、银缕梅属 (Parrotia)、香果树属 (Emmenopterys)、秤锤树属 (Sinojackia)、青檀属

表 1 浙江省特有植物的区域性分布

Table 1 Regional distribution of the endemic species in Zhejiang Province

\begin{tabular}{|c|c|c|c|c|}
\hline $\begin{array}{l}\text { 编号 } \\
\text { No. }\end{array}$ & $\begin{array}{l}\text { 区域 } \\
\text { Region }\end{array}$ & $\begin{array}{l}\text { 自然保护区和主要山地 } \\
\text { Nature reserves and related mountains }\end{array}$ & $\begin{array}{l}\text { 中国特有属数 } \\
\text { No. of genera } \\
\text { endemic to China }\end{array}$ & $\begin{array}{c}\text { 本区内浙江特有种数 } \\
\text { No. of species } \\
\text { endemic to Zhejiang } \\
\text { in the region }\end{array}$ \\
\hline $\mathrm{I}$ & $\begin{array}{l}\text { 浙江西北部山区 } \\
\text { Mountainous region in NW Zhejiang }\end{array}$ & $\begin{array}{l}\text { 天目山自然保护区 } \\
\text { Tianmushan Nature Reserve } \\
\text { 清凉峰自然保护区 } \\
\text { Qingliangfeng Nature Reserve } \\
\text { 龙王山自然保护区 } \\
\text { Longwangshan Nature Reserve }\end{array}$ & $\begin{array}{l}25 \\
20 \\
17\end{array}$ & 53 \\
\hline II & $\begin{array}{l}\text { 浙江西部山区 } \\
\text { Mountainous region in W Zhejiang }\end{array}$ & $\begin{array}{l}\text { 开化及古田山自然保护区 } \\
\text { Kaihua and Gutianshan Nature Reserve }\end{array}$ & 11 & 8 \\
\hline III & $\begin{array}{l}\text { 浙江西南部山区 } \\
\text { Mountainous region in SW Zhejiang }\end{array}$ & $\begin{array}{l}\text { 遂昌、松阳 } \\
\text { Suichang and Songyang Counties }\end{array}$ & 22 & 40 \\
\hline \multirow[t]{2}{*}{ IV } & $\begin{array}{l}\text { 浙江南部山区 } \\
\text { Mountainous region in S Zhejiang }\end{array}$ & $\begin{array}{l}\text { 风阳山 - 百山祖自然保护区 } \\
\text { Fengyangshan-Baishanzu Nature Reserve } \\
\text { 景宁县及乌岩岭自然保护区 } \\
\text { Wuyanling Nature Reserve and Jingning } \\
\text { County }\end{array}$ & $\begin{array}{l}18 \\
13\end{array}$ & 57 \\
\hline & $\begin{array}{l}\text { 浙东山区 } \\
\text { Mountainous region in E Zhejiang }\end{array}$ & $\begin{array}{l}\text { 临海、仙居、缙云县境内的括苍山区 } \\
\text { Kuocang Mountains in Linhai , Xianju and } \\
\text { Jinyun Counties }\end{array}$ & 15 & 12 \\
\hline V & $\begin{array}{l}\text { 浙东丘陵 } \\
\text { Hilly land in E Zhejiang }\end{array}$ & $\begin{array}{l}\text { 天台山区 } \\
\text { Tiantai Mountains }\end{array}$ & 18 & 20 \\
\hline VI & $\begin{array}{l}\text { 浙东海岛 } \\
\text { Islands in E Zhejiang }\end{array}$ & $\begin{array}{l}\text { 普陀山及附近岛屿 } \\
\text { Putuoshan Island and nearby islands }\end{array}$ & 9 & $4 \sim 5$ \\
\hline
\end{tabular}


表 2 目的物种中浙江特有植物的数量及分布情况

Table 2 Amount and distribution of the endemic plants among the target species in Zhejiang Province

\begin{tabular}{|c|c|c|c|}
\hline $\begin{array}{c}\text { 物种 } \\
\text { Species }\end{array}$ & $\begin{array}{l}\text { 资源数量 } \\
\text { Individual amount }\end{array}$ & $\begin{array}{c}\text { 分布面积 } \\
\text { Distribution area }\left(\mathrm{hm}^{2}\right)\end{array}$ & $\begin{array}{c}\text { 分布及生境 } \\
\text { Distribution and habitats }\end{array}$ \\
\hline $\begin{array}{l}\text { 银杏 } \\
\text { Ginkgo biloba }\end{array}$ & 242 & 34.81 & $\begin{array}{l}\text { 临安西天目山、临目, 安吉龙王山, 海拔 } 400 \sim 1100 \mathrm{~m} \\
\text { Xitianmushan and Linmu in Lin' an, Longwangshan in Anji, } \\
\text { alt. } 400 \sim 1100 \mathrm{~m}\end{array}$ \\
\hline $\begin{array}{l}\text { 百山祖冷杉 } \\
\text { Abies beshanzuensis }\end{array}$ & 3 & 0.10 & $\begin{array}{l}\text { 庆元百山祖 海拔 } 1740 \mathrm{~m} \text {, 亮叶水青冈林中 } \\
\text { Baishanzu in Qingyuan , alt. } 1740 \mathrm{~m} \text { in beech forest }\end{array}$ \\
\hline $\begin{array}{l}\text { 九龙山榧 } \\
\text { Torreya grandis var. } \\
\text { jiulongshanensis }\end{array}$ & 15 & 0.2 & $\begin{array}{l}\text { 遂昌九龙山、缙云石笕、磐安、天台石梁, 沟谷林中 } \\
\text { Jiulongshan in Suichang , Shijian in Jinyun, Pan'an ,Shiliang in } \\
\text { Tiantai , in valley forest }\end{array}$ \\
\hline $\begin{array}{l}\text { 羊角械 } \\
\text { Acer yangjuechi }\end{array}$ & 4 & 0.20 & $\begin{array}{l}\text { 临安西天目山, 海拔 } 800 \sim 870 \mathrm{~m} \text {, 沟谷林中 } \\
\text { Xitianmushan in Lin'an , alt. } 800 \sim 870 \mathrm{~m} \text { in valley forest }\end{array}$ \\
\hline $\begin{array}{l}\text { 普陀鹅耳枥 } \\
\text { Carpinus putoensis }\end{array}$ & 1 & 0.01 & $\begin{array}{l}\text { 舟山普陀山岛 } \\
\text { Putuoshan Island in Zhoushan }\end{array}$ \\
\hline $\begin{array}{l}\text { 天台鹅耳枥 } \\
\text { Carpinus tientaiensis }\end{array}$ & 21 & 0.30 & $\begin{array}{l}\text { 天台华顶山 海拔 } 800 \sim 1000 \mathrm{~m} \text { 山坡林中 } \\
\text { Huadingshan in Tiantai alt. } 800 \sim 1000 \mathrm{~m} \text {, in hillside forest }\end{array}$ \\
\hline $\begin{array}{l}\text { 天目铁木 } \\
\text { Ostrya rehderiana }\end{array}$ & 5 & 0.40 & $\begin{array}{l}\text { 临安西天目山, 沟谷两侧 } \\
\text { Xitianmushan in Lin'an , along both sides of valley }\end{array}$ \\
\hline $\begin{array}{l}\text { 夏腊梅 } \\
\text { Calycanthus chinensis }\end{array}$ & 1732214 & 2443.03 & $\begin{array}{l}\text { 临安顺溪镇、颊口镇、龙岗镇, 天台大雷山 } \\
\text { Shunxi Jiakou and Longgang in Lin'an , and Daleishan in Tian- } \\
\text { tai }\end{array}$ \\
\hline $\begin{array}{l}\text { 浙江雪胆 } \\
\text { Hemsleya zhejiangensis }\end{array}$ & 4950 & 0.11 & $\begin{array}{l}\text { 泰顺乌岩岭 海拔 } 750 \mathrm{~m} \text {, 沟边林下 } \\
\text { Wuyanling in Taishun , alt. } 750 \mathrm{~m} \text { under valley foresrt }\end{array}$ \\
\hline $\begin{array}{l}\text { 华顶杜鹃 } \\
\text { Rhododendron huadingense }\end{array}$ & 330 & 1.70 & $\begin{array}{l}\text { 天台华顶山 海拔 } 750 \sim 950 \mathrm{~m} \text {,山坡林中 } \\
\text { Huadingshan in Tiantai , alt. } 750 \sim 950 \mathrm{~m} \text {, in hillside forest }\end{array}$ \\
\hline $\begin{array}{l}\text { 天台水青冈 } \\
\text { Fagus tientaiensis }\end{array}$ & 1 & 0.20 & $\begin{array}{l}\text { 天台石梁, 石梁瀑布旁 } \\
\text { Shiliang in Tiantai, beside waterfall }\end{array}$ \\
\hline $\begin{array}{l}\text { 浙江润楠 } \\
\text { Machilus chekiangensis }\end{array}$ & 4 & 0.02 & $\begin{array}{l}\text { 杭州灵隐 ,山坡林中 } \\
\text { Linying in Hangzhou, in hillside forest }\end{array}$ \\
\hline $\begin{array}{l}\text { 景宁木兰 } \\
\text { Magnolia sinostellata }\end{array}$ & 61 & 6.70 & $\begin{array}{l}\text { 景宁草鱼塘 , 海拔 } 900 \sim 1100 \mathrm{~m} \text { 沟谷 } \\
\text { Caoyutang in Jingning, alt. } 900 \sim 1100 \mathrm{~m} \text {, in valley }\end{array}$ \\
\hline $\begin{array}{l}\text { 玉兰叶石楠 } \\
\text { Photinia magnoliifolia }\end{array}$ & 10 & 0.60 & $\begin{array}{l}\text { 临安青山湖边 } \\
\text { Along Qingshan lakesides in Linan }\end{array}$ \\
\hline $\begin{array}{l}\text { 细果秤锤树 } \\
\text { Sinojackia microcarpa }\end{array}$ & 1052 & 2.83 & $\begin{array}{l}\text { 建德泷江 ,临安青山湖旁 } \\
\text { Longjiang in Jiande, and Qingshan lakesides in Lin'an }\end{array}$ \\
\hline $\begin{array}{l}\text { 浙江安息香 } \\
\text { Styrax zhejiangensis }\end{array}$ & 10 & 0.10 & $\begin{array}{l}\text { 建德泷江 } \\
\text { Longjiang in Jiande }\end{array}$ \\
\hline $\begin{array}{l}\text { 浙江蝎子草 } \\
\text { Girardinia chingiana }\end{array}$ & 2340 & 1.09 & $\begin{array}{l}\text { 临安西天目山 , 沟谷林下 } \\
\text { Xitianmushan in Lin'an , under valley forest }\end{array}$ \\
\hline
\end{tabular}

(Pteroceltis)、白穗花属 (Speirantha) 等,这些特有属 基本上是一些单种属或寡种属，起源古老，它们对于 研究浙江省乃至中国植物区系以及植物的系统发育 和物种多样性形成具有极为重要的价值。此外, 还 有浙江特有植物 17 种(见表 2 ) ,中国特有植物 56 种，占目的物种总数的 $72.7 \%$ 。有许多以浙江为分 布中心的珍稀物种或浙江准特有种也绝大多数分布 在上述区域，如金钱松 (Pseudolarix amabilis)、白豆 杉(Pseudotaxus chienii)、榧树 (Torreya grandis)、银 缕梅 (Parrotia subaequalis)、普陀樟 (Cinnamomum ja- ponicum var. chenii)、舟山新木姜子 ( Neolitsea sericea)、浙江楠 (Phoebe chekiangensis)、长序榆( Ulmus elongata)、百日青 (Podocarpus neriifolius)、七子花 ( Heptacodium miconioides)、日本荚蒾（Viburnum japonicum)、日本珊瑚树 (Viburnum odoratissimum var. awabuki)、长柄双花木 (Disanthus cercidifolius var. longipes)、天目木姜子( Litsea auriculata) 等。

\section{3 水平分布格局}

从植物物种多样性方面分析, 天目山有维管植 物 186 科 832 属 1869 种(包括种下分类单位,下 
同）;清凉峰有种子植物 144 科 687 属 1469 种; 龙王 山有维管植物 156 科 685 属 1395 种;九龙山有维管 植物 179 科 684 属 1568 种;古田山有维管植物 189 科 755 属 1666 种;乌岩岭有维管植物 168 科 655 属 约 1500 余种; 汉阳山、百山祖自然保护区有维管植 物 209 科 910 属 2241 种; 大洋山有种子植物 136 科 540 属 1126 种; 仙居俞坑有维管植物 163 科 49 属 1440 种;浙江海岛有维管植物 177 科 757 属 1555 种。以上这些地区分布着浙江省约 $90 \%$ 以上的植 物物种和绝大多数的珍稀濒危植物。

从调查的 77 个目的物种来看，它们遍布全省 75 个县 (包括县级市、区，下同）, 但在水平分布上是 极不均匀的。从各县调查到的目的物种的数量上可 以看出，分布有目的物种较多 (10 种或以上) 的县仅 19 个,最多的 8 个县是:临安 (36 种)、龙泉 (20 种)、 遂昌 (20 种)、松阳 (17 种)、庆元 (17 种)、天台 (15 种)、安吉 (15 种)、永嘉 (14 种); 6 9 种的有 22 个 县;而不到 6 种的有 34 个县 (占全省 $45 \%$ 以上)。 从调查物种的个体数量上看,其水平格局也呈明显 的聚集性, 分布中心基本上与上述物种数量分布情 况一致。

\section{2 浙江珍稀濒危植物受威胁状况}

野生植物资源的过渡利用和生境严重片断化是 浙江省珍稀濒危植物所面临的主要威胁。浙江省人 口众多，开发历史悠久，在野生植物中，许多优良的 森林树种和药用、经济植物历来都是开发利用的主 要对象。长期以来 野生无主, 谁采谁有” 的观念在 许多林农头脑中根深蒂固, 加之经济利益的驱动和 法制观念、保护意识的淡薄, 随意乱采乱挖、过度采 挖的现象相当普遍, 对许多野生植物资源造成严重 的破坏, 野生珍稀濒危植物也因此受到严重威胁。 如福建柏 (Fokienia hodginsii)、闽楠 (Phoebe bour$n e i$ )、樟树 (Cinnamomum camphora)、毛红椿 (Toona ciliata var. pubescens)、长序榆、红豆树 (Ormosia hosiei)、花榈木 (Ormosia henryi)、榉树 (Zelkova schneideriana) 等因其木材质优价贵而遭到严重破坏; 金 毛狗 (Cibotium barometz)、杜仲 (Eucommia ulmoides)、南方红豆杉 ( Taxus wallichiana var. mairei)、凹叶厚朴 (Magnolia officinalis subsp. biloba)、短萼黄连 (Coptis chinensis var. brevipetiolata)、 竹节人参 (Panax japonicus) 等因其树皮或全株具药
用价值而遭到严重砍伐和挖掘破坏; 兰花( Cymbidi$u m$ )、白穗花 (Speirantha gardenii)、玉蝉花 (Iris ensa$t a$ )、海滨木槿 (Hibiscus hamabo) 等因其具有观赏价 值而遭到乱采滥挖的破坏。近年来, 由于城市绿化 和城市林业的发展,一些单位和个人直接从山上挖 掘野生大树用于城市绿化, 致使一些野生植物的分 布区面积急剧缩减, 野生资源明显减少。

浙江省珍稀濒危野生植物多数仅分布在残留的 天然阔叶林中或一些特殊的生境中。近年来, 虽然 在浙江省自然保护区内的珍稀濒危野生植物得到了 较好的保护, 但分布在自然保护区外的珍稀濒危植 物却面临着生境严重破碎的直接威胁, 尤其是对天 然林的滥砍乱伐、毁林开荒, 造成了多种重点保护野 生植物适生生境面积的缩小和非连续性分布, 如短 颌黄连只生长在海拔 385 1700 m 的沟谷森林下, 由于生境的破坏, 种群间个体迁移被切断, 加速了物 种的灭绝。又如伯乐树 (Bretchneidera sinensis)、南 方红豆杉等生长于多种生境类型中, 由于生境的片 断化而被分隔成若干小种群, 使物种生境异质性消 失, 从而加剧了这些物种的濒危程度。生境的破坏 和严重片断化还有可能直接造成物种局部灭绝, 例 如缙云大洋山在 20 世纪 80 年代末发现的七子花、 锈毛羽叶参 (Pentapanax henryi) 等物种, 由于当地森 林的破坏而在本次调查中未发现。

根据调查物种分析，目前已经在自然保护区、国 家森林公园、风景区或国营林场内得到较妥善的就 地保护的珍稀濒危野生植物物种仅约占总数的 $2 / 3$ 。 也就是说, 还有 $1 / 3$ 的重点保护野生植物随时有可 能遭到毁灭性破坏, 如缙云大洋山的白豆杉、福建 柏、长叶榧 (Torreya jackii) 等, 临安顺溪的夏腊梅 (Sinocalycanthus chinensis)、榉树等，平阳、泰顺雅阳 等地的金毛狗等均面临着生境被破坏、被砍伐、被人 为挖掘的严重威胁。

浙江省重点保护野生植物多数是小种群物种, 生境的严重破碎化直接影响到这些小种群植物的生 存。虽然近年来浙江省的自然保护区建设取得了很 大的进步, 但其数量和面积、地域分布等都还不能适 应野生动植物保护的需要。

从浙江特有种资源的数量及分布可以看出, 除 夏腊梅外, 大多数种类分布范围极其狭窄, 分布点仅 $1 \sim 2$ 个, 面积极小, 个体数量极少, 充分说明了这些 物种对环境要求的严格程度及自身对环境适应的脆 
弱性。这些特有种多数为古老残遗特有种, 如银杏 (Ginkgo biloba)、百山祖冷杉 (Abies beshanzuensis)、 天目铁木 (Ostrya rehderiana) 、羊角械 (Acer yangjuechi)、天台水青冈( Fagus tientaiensis)、普陀我耳枥 (Carpinus putoensis)、天台鹅耳枥 (Carpinus tientaien$s i s)$ 等。但也有少数物种属于在系统发育上处于进 化位置较高的新特有植物, 如浙江雪胆 (Hemsleya zhejiangensis)、华顶杜鹃 (Rhododendron huadingense)、浙江安息香 (Styrax zhejiangensis) 等,而这些 新特有植物也正面临着生境受到破坏的严重威胁， 叒待保护。

\section{3 浙江珍稀濒危植物物种多样性保护的关 键区域}

通过浙江省野生维管植物物种及珍稀濒危植物 资源的分布格局、特有现象的分析表明，浙江省应优 先保护的植物物种的分布是不均匀的,有些地区重 要的保护对象比较集中，对这些地区我们应该给予 更多的保护, 这就是本文所指的植物物种多样性保 护的关键区域。根据维管植物物种的丰富程度、珍 稀濒危植物的物种数量及个体数量特征、受威胁状 况以及浙江省特有植物的分布情况，在此提出 7 个 具有重要保护意义的浙江省珍稀濒危植物物种多样 性关键区域（见表 3 ), 这 7 个关键区域分布着全省 $90 \%$ 以上的植物物种和绝大多数的珍稀濒危或特有
植物。

3.1 以西天目山为中心的浙西北山区 (图 1.I) 本区是浙江省境内保护植物分布最为集中的区 域。以天目山国家级自然保护区为中心, 向北延伸 至安吉南部龙王山省级自然保护区, 向西南方向延 伸到临安西部的清凉峰国家级自然保护区,总面积 约 $26.80 \times 10^{4} \mathrm{hm}^{2}$ 。本区位于中亚热带北缘至北亚 热带过渡地带, 地质古老, 地势起伏剧烈, 高山深谷 相间, 气候温和, 季风强盛, 四季分明, 雨量充沛, 光 照适宜, 复杂多变的森林小气候构成了独特的自然 环境, 为许多古老珍稀物种的保存和丰富的物种多 样性创造了有利条件。该区植物资源丰富, 植被保 存较为完好珍稀濒危植物多。目的物种中, 本区特 有的有银杏、天目铁木、夏腊梅、羊角械、玉兰叶石楠 (Photinia magnoliifolia)、细果秤锤树 (Sinojackia microcarpa)、浙江蝎子草 (Girardinia chingiana) 等 7 种, 其中天目铁木仅存 5 株, 羊角械仅存 4 株; 在浙 江仅分布于本区的植物有银缕梅、毛柄小勾儿茶 (Berchemiella wilsonii var. pubipetiolata) 2 种;华东黄 杉( Pseudotsuga sinensis) 、金钱松、榧树、锈毛羽叶 参、连香树 (Cercidiphyllum japonicum)、领春木 (Euptelea pleiosperma )、天目木姜子、白穗花、玉蝉花、睡菜 (Menyanthes trifoliata)、平枝栒子 (Cotoneaster hor izontalis）、黄山梅（Kirengeshoma palmata）、膀胱

表 3 浙江省保护珍稀濒危植物物种多样性关键区域的珍稀濒危植物统计

Table 3 The statistics of the rare and endangered plants species in the critical regions in Zhejiang Province

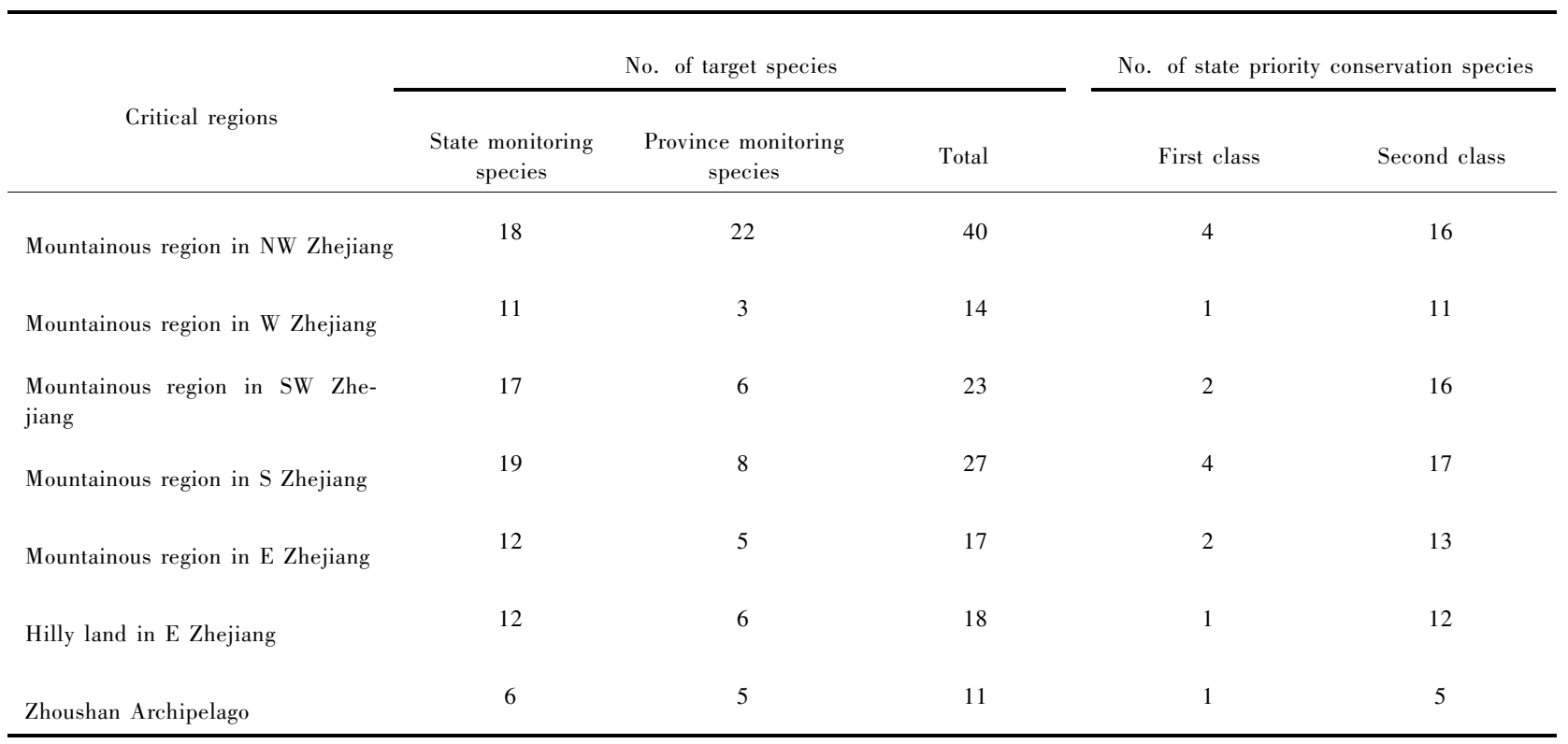




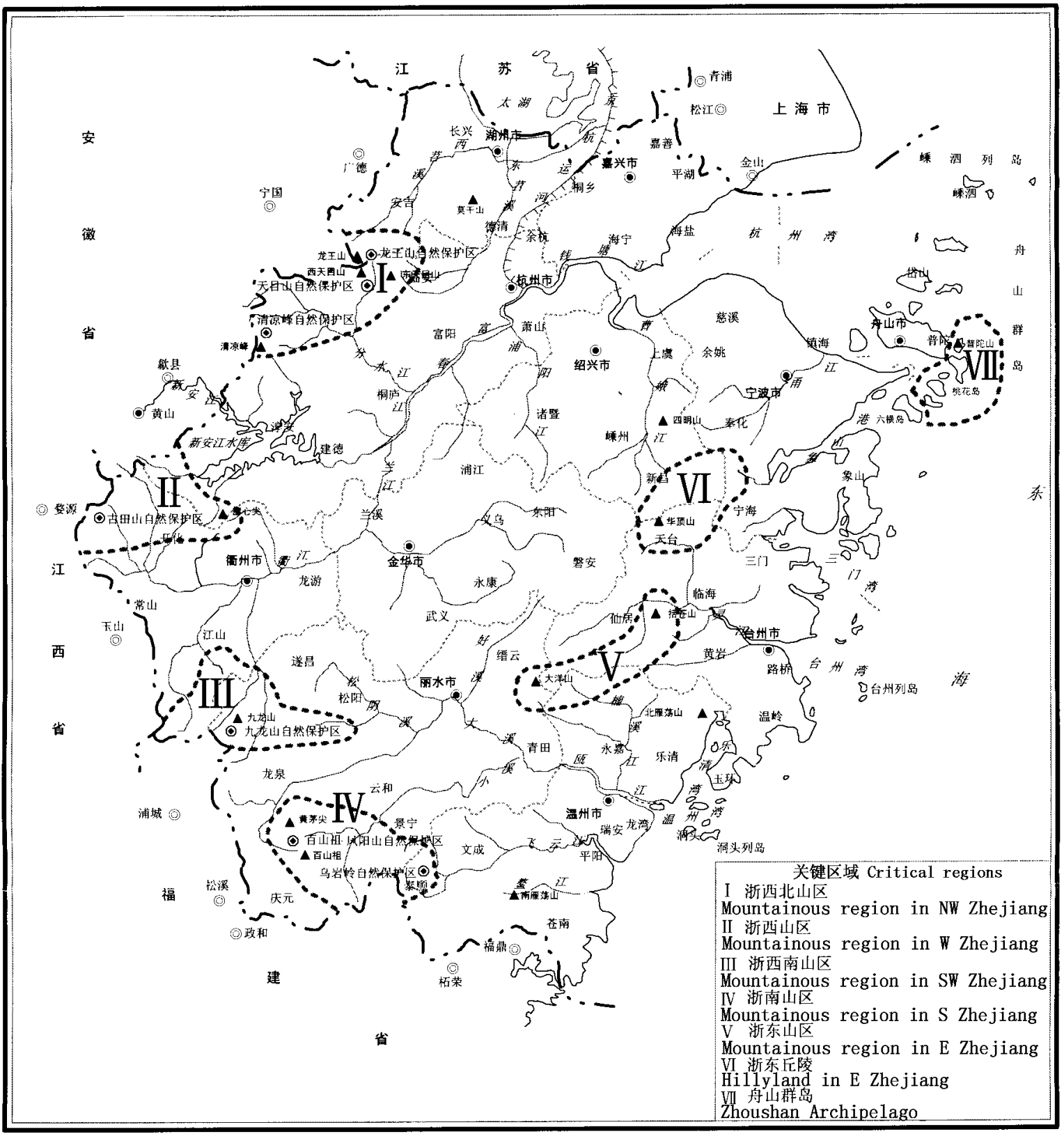

图 1 浙江省植物资源保护关键区域图

Fig. 1 The critical regions for conservation of the rare and endangered plant species diversity in Zhejiang Province

果 ( Staphylea holocarpa)、青 檀 ( Pteroceltis tatarinowii)、杜仲、腊梅 (Chimonanthus praecox)、圆柏 (Sabina chinensis)、鹅掌楸 (Liriodendron chinense) 等 目的物种在浙江范围内以此为主要分布区, 其中华 东黄杉、金钱松、榧树、天目木姜子、白穗花、玉蝉花 等在全国具有重要地位。

此外, 这里是浙江特有植物分布的中心之一, 集中了 30 个中国特有属和 60 多个浙江特有植物， 如天目早竹 (Phyllostachys tianmuensis)、昌化铁线蕨
(Adiantum subpedatum)、龙塘山谷精草 (Eriocaulon sikokianum var. linanense)、天目朴 (Celtis chekiangensis)、天目凤仙花 (Impatiens tienmushanica) 、白花土 元胡 (Corydalis humosa)、象鼻兰 (Nothodoritis zhejiangensis) 等等。

3.2 以古田山为中心的浙西山区 (图 1. II) 本区以开化县西北部古田山国家级自然保护区 为中心, 向东北延伸至浙皖竷边境的齐溪森林公园, 再转东南至淳安县南部的磨心尖, 属怀玉山脉的东 
段，总面积约 $21.50 \times 10^{4} \mathrm{hm}^{2}$, 区内地质古老，山体 陡峭, 地势险要, 地形复杂, 雨量充沛, 热量充足, 空 气湿润，夏凉多雨，形成独特的小气候环境。本区位 于典型常绿阔叶林分布区，天然植被保存较好蕴藏 着丰富的生物多样性。目的物种中, 长柄双花木、南 方红豆杉等在浙江范围内以此为主要分布区。本区 还分布着 13 个中国特有属和 10 种浙江特有植物， 如江山鳞毛蕨 (D. jiangshanensis)、浙江葚奥 (Vitis zhejiang-adstricta)、建德荠苧（Mosla hangchowensis var. cheteana) 等。

\section{3 以九龙山为中心的浙西南山区 (图 1. III)}

本区位于浙赣闽三省交界处, 以九龙山省级自 然保护区为中心，包括了衔县南部的大源尾和遂昌 县西南部、南部的大部分山区、龙泉市西北部山区以 及往东延伸到松阳县西南部的箬寮岘自然保护区， 属仙霞岭的东北段，总面积约 $22.30 \times 10^{4} \mathrm{hm}^{2}$ 。本 区是浙江省最偏僻的地区之一, 平均海拔 $1000 \mathrm{~m}$ 以 上, 区内人烟稀少, 地势高峻、谷深水急、群峰云集, 湿润多雨的气候和特殊的自然环境条件以及保存较 为完好的森林植被孕育了丰富的生物多样性。目的 物种中，在浙江仅分布于本区的有鞭打绣球 ( Hemiphragma heterophyllum) 等，此外，白豆杉、百日青、伯 乐树、九龙山榧 (Torreya grandis var. jülongshanensis)、毛红椿等目的物种在浙江以此为主要分布区。 本区还有浙江特有种 40 多个和中国特有属 22 个， 如九龙山鳞毛茨 (Dryopteris jiulungshanensis)、浙江 瘤足彍 ( Plagiogyria chekiangensis) 、遂昌冬青 (Ilex suichangensis)、遂昌雷竹 (Phyllostachys primotina)、 九龙山景天 (Sedum juulungshanensis) 、大西坑水玉筧 (Burmannia cryptopetala var. daxikangensis) 等。

3.4 以凤阳山 - 百山祖为中心的浙南山区 (图 1. IV )

本区以凤阳山 - 百山祖国家级自然保护区为中 心, 向东南方向延伸至泰顺乌岩岭国家级自然保护 区，包括景宁县西南部山区，总面积约 $25.50 \times 10^{4}$ $\mathrm{hm}^{2}$ 。本区是中国生物多样性保护关键区域一一浙 闽赣山区的一部分（国家环保局，1998），平均海拔 $1000 \mathrm{~m}$ 左右 地处中亚热带, 气候属 南岭闽瓯中亚 热带” 气候区, 雨量充沛, 相对湿度大, 温暖湿润多 云雾, 生物资源丰富, 是我省植物多样性分布最集中 的区域，也是浙江省华东植物区系成份集中分布所 在。凤阳山主峰黄茅尖海拔 $1929 \mathrm{~m}$, 为浙江第一高
峰。在庆元县百山祖海拔 $1740 \mathrm{~m}$ 左右的山地, 1976 年首次发现百山祖冷杉 (Abies beshanzuensis) 8 株, 现 仅残存 3 株, 1987 年被国际物种生存保护委员会 (SSC) 公布为世界上受威胁最严重的 12 个濒危物 种之一。除百山祖冷杉外, 本区还有 29 个中国特有 属和 50 多个浙江特有种, 如浙江雪胆、景宁木兰 (Magnolia sinostellata)、粉红短柱茶 (Camellia puniceiflora)、龙泉葡萄 (Vitis longquanensis)、浙江过路黄 ( Lysimachia chekiangensis)、云和假精苏 (Paraphlomis lancidentata) 、百山祖玉山竹 (Yushania baishanzuensis)、浙江猕猴桃 (Actinidia zhejiangensis) 等, 此外, 本 次调查中的莼菜 (Brasenia schreberi)、金毛狗、福建 柏、闽楠、红豆树、南方红豆杉、假地枫皮(Illicium angustisepalum)、凹叶厚朴、短蓦黄连等目的物种在 浙江以此为主要分布区。

\section{5 以括苍山为中心的浙东山区 (图 1.V)}

本区自临海县西部括苍山向西南经仙居县南部 俞坑自然保护区到缙云县东南部大洋山林区, 平均 海拔约 $800 \mathrm{~m}$, 全境跨越 80 余公里, 总面积约 17.20 $\times 10^{4} \mathrm{hm}^{2}$ 。本区属中亚热带中山区,地形起伏剧 烈, 间以深潭瀑布, 气候湿润多云雾, 受海洋影响较 大，水热条件良好，形成了独特的自然条件和丰富的 生物资源。在浙江仅分布于本区的目的物种有刺叶 栎等, 此外, 长叶榧、七子花等目的物种在浙江范围 内以此为主要分布区。

本区的中国特有属有 17 个, 浙江特有种 11 种， 主要有温州冬青 (Ilex wenchowensis)、温州长蒴苣苔 (Didymocarpus cortusifolius)、仙白草 (Aster turbinatus var. chekiangensis) 等。由于长期的经营活动, 天然 植被破坏较为严重, 目前完好的天然林所剩无几。 为保护好本区的生物多样性, 在区域内建立省级自 然保护区以及在珍稀植物较为集中的山区建立自然 保护小区是十分必要的。

3.6 以天台山为中心的浙东丘陵 (图 1.VI)

本区是天台山的西南段, 以华顶山森林公园为 中心,包括天台县北部, 宁海县西南部和新昌县的东 南部山区, 总面积约 $16.60 \times 10^{4} \mathrm{hm}^{2}$ 。本区属浙东 丘陵山地, 平均海拔 $500 \sim 600 \mathrm{~m}$, 地形起伏多变, 气 候温和、水热条件良好, 植物生长繁茂, 并保存了一 定面积较为完好的森林植被, 植物多样性丰富。天 台县石梁镇中方广寺石梁飞瀑旁, 海拔 $600 \mathrm{~m}$ 的沟 谷甜槠青冈栎林中的天台水青冈(Fagus tientaien- 
sis) 现仅存 1 株。此外，本区特有的目的物种还有天 台鹅耳枥、华顶杜鹃等，七子花等目的物种在浙江范 围内以此为主要分布区。

在本区分布的中国特有属有 18 个, 浙江特有种 20 种左右。除上述特有植物以外, 主要有光紫茎 (Stewartia glabra)、美丽毛鸡爪槭 (Acer pubipalmatum var. pulcherrimum) 、雁荡三角槭 (A. buergerianum var. yentangense)、天台鸭嘴草 (Ischaemum tientaiense)、天台铁线莲 (Clematis patens subsp. tientaiensis)、浙江冬青 (Ilex zhejiangensis) 等。

\section{7 以普陀山为中心的舟山群岛 (图 1.VII)}

本区以普陀山为中心包括洛珈山、朱家尖、桃花 岛等岛屿, 陆域面积约 $1.55 \times 10^{4} \mathrm{hm}^{2}$ ，以丘陵地貌 为主, 海拔 $300 \mathrm{~m}$ 以下。海洋性气候是本区气候的 主要特点, 四季分明, 光照充足, 气温适中, 热量丰 富, 降水量相对偏少 (年降水940 1 $1350 \mathrm{~mm}$ )。本 区的植物物种多样性虽然不及其他区域丰富，但在 我国沿海岛屿生态系统中具有代表性, 是浙江省中 国 - 日本植物区系成份的集中分布所在。局部地区 尚保存一定面积的森林植被, 而在滨海区虽然没有 茂密的森林, 却分布着一些独特的海滨植物群落。 浙江特有的普陀鹅耳杯 20 世纪 50 年代在普陀山有 数处发现, 50 年代末至 60 年代初, 普陀山森林树木 遭到乱砍滥伐, 毁林开荒, 原有的植株日益减少(卢 小根，1992）现仅存 1 株，已濒临灭绝。本区还有普 陀樟、普陀孝顺竹 (Bambusa glaucescens form. lut$e a$ )、倒向鳞毛蕨 (Dryoperis retroso-paleacea) 等浙江 特有种, 以及在浙江仅分布于本区的有舟山新木姜 子、日本女贞 (Ligustrum japonicum)、日本珊瑚树等。 此外, 海滨木槿、红山茶 (Camellia japonica)、寒竹 (Chimonobambusa marmorea) 等目的物种在浙江范 围内以此为主要分布区。

\section{4 浙江植物物种多样性保护的建议}

\section{1 加强保护区和保护小区的建设}

目前浙江省已有各类动植物自然保护区 15 个, 总面积 $7.8 \times 10^{4} \mathrm{hm}^{2}$ ，占全省陆域面积的 $7.66 \%$ ，但 从野生动植物物种多样性保护的需要来看, 其数量、 面积还不足，布局还欠合理。应在现有保护区的基 础上,适当扩大保护区面积或提升保护区级别; 在未 建保护区的关键区域建立野生动植物自然保护区; 对分布在保护区和关键区域以外的濒危植物小种群
物种建立保护点或保护小区, 是抢救这些濒危物种 的最有效措施。例如,把九龙山省级自然保护区提 升为国家级自然保护区, 仙居愈坑自然保护区、松阳 箬寮笕自然保护区可提升省级自然保护区; 在缙云 大洋山、淳安磨心尖和衢县大源尾等山地建立省级 自然保护区。另外, 应加强国家或省级森林公园植 物多样性的保护, 在珍稀濒危植物比较集中的地区 建立保护小区或保护点。尤其值得注意的是一些极 度濒危的物种, 如百山祖冷杉、天台水青冈、普陀鹅 耳杤等, 当地政府和主管部门应予以高度重视, 尽快 采取有效措施加强保护。

\section{2 加强生物多样性保护的基础研究工作}

本次调查是我国首次对重点保护的野生植物的 个体数量、分布面积及生境等方面进行全面系统的 调查。浙江省在本次调查中取得了有关 77 个目的 物种的数量、分布面积及生境状况大量的第一手资 料, 发现了许多新分布点, 把浙江省的珍稀濒危野生 植物资源调查研究大大地向前推进了一步。但是, 无论是在浙江省还是国内其他各省, 受威胁的物种 远不止这个数。《浙江植物志》总论卷 (浙江植物志 编辑委员会, 1993) 提出了浙江省 125 种的珍稀濒危 植物名录, 其中包括建议列入保护的植物 70 种; 张 若惠等 (1994) 描述了浙江珍稀濒危植物 160 余种， 其中包括省级重点保护植物 100 余种。但根据权威 学者的意见, 世界上约 $10 \%$ 的现存物种受到不同程 度的威胁 (Myers，1988) , 照此估计浙江维管植物中 受威胁的物种就应有 400 种左右。而且从资源现状 来看也确实如此, 如我省已十分稀少的中华水非 (Isoetes sinensis)、天目朴、羽毛球树 (Buckleya lanceolata)、圆叶小石积 (Osteomeles subrotunda)、老虎刺 (Pterolobium punctatum)、全缘冬青 (Ilex integra)、翻 白叶树 (Pterospermum heterophyllum)、竹节人参、倒 卵叶瑞香 (Daphne grueningiana)、明党参 (Changium smyrnioides)、延龄草 (Trillium tschonoskii) 、天目贝母 (Fritillaria monantha)、毛鳞省藤 (Calamus thysanolepis)、独花兰 (Changnienia amoena) 等都未列入本次 调查的范围。

为了对所需重点保护的珍稀濒危野生植物物种 进行更有效的保护, 必须重视基础研究工作,包括这 些珍稀濒危野生植物的分布范围、分布格局、物种的 种群大小、种群变化趋势、种群特性 (是否为小种 群)、栖息地类型和状况、致濒原因等有必要进行全 
面调查研究。进一步研究这些物种的受威胁方式和 受威胁程度, 种群数量或分布面积下降的过程和原 因等。在深入调查研究的基础上提出科学的优先保 护序列并制定合理的保护策略，在这方面世界自然 保护联盟濒危等级标准 ( IUCN ,1994) 的定量指标很 好地解决了此问题,但要具体确定每个物种受威胁 等级则需要做大量的基础研究工作。

参考文献

国家环保局, 1998. 中国生物多样性国情研究报告. 北京: 中 国环境科学出版社

卢小根, 刍达明, 1992. 普陀鹅耳枋濒危原因的调查研究. 见: 宋朝枢 (主编) : 主要珍稀濒危树种繁殖技术. 北京: 中国林业出版社
应俊生, 张玉龙, 1994. 中国种子植物特有属. 北京: 科学出 版社

张若蕙, 楼炉焕, 李根有, 1994. 浙江珍稀濒危植物. 杭州: 浙 江科学技术出版社

浙江植物志编辑委员会, 1989 1993. 浙江植物志 ( 第 $1 \sim 7$ 卷, 总论卷). 杭州: 浙江科学技术出版社

郑朝宗, 倪穗, 丁炳扬, 1998. 浙江分布的中国种子植物特有 属研究. 杭州大学学报, 25(2): 75 80

Myers N, 1988. Threatened biotas: "Hotspots" in tropical forests. Environmentalist, 8: $1 \sim 20$

IUCN, 1994. IUCN Red List Categories. IUCN, Gland, Switzerland

(责任审稿人：郑朝宗；责任编辑：时意专)

\section{《生物多样性》2001 年度优秀论文奖}

经我刊 $2 / 3$ 以上编委投票, 并经编委会讨论评选出 2001 年度优秀论文奖, 公布如下：

黄建辉，白永飞，韩兴国. 物种多样性与生态系统功能 :影响机制及有关假说. 2001,9

(1) : $1 \sim 7$

应俊生. 中国种子植物物种多样性及其分布格局. 2001 9(4) 393 ３98

陆凡, 郑小波, 陈志谊, 刘永峰, 王法明, 范永坚. 江苏省稻瘟病菌的毒性多样性及水稻品 种的抗病性. 2001 9(3) $201 \sim 206$

本刊将对以上作者颁发荣誉证书、赠送 2002 年全年刊物并给予一定的物质奖励。 